\title{
Effect of Dates of Sowing and Fertilizer on Growth and Seed Yield of Sunnhemp Genotypes
}

\author{
Sanggonda $^{1^{*}}$, M.R. Eshanna ${ }^{2^{*}}$ and M. Priyanka ${ }^{3^{*}}$ \\ Department of Seed Science and Technology, University of Agricultural Sciences, \\ Dharwad-580005, India \\ *Corresponding author
}

\section{A B S T R A C T}

\section{Keywords}

Dates of sowing, Fertilizer levels, Genotypes, Plant height, Dry matter, Seed yield

\section{Article Info}

Accepted:

22 October 2019

Available Online:

10 November 2019
A field experiment was conducted during kharif 2016, to study the effect of date of sowing and fertilizer application on seed yield and quality of Sunnhemp genotypes (Crotalaria juncea L.) at Agricultural Research Station, Kalloli, Gokak taluk Belagavi district, University of Agricultural Sciences, Dharwad. The field experiment comprised of twenty-four treatments with three replications in double split plot design. Among different dates of sowing,D3-First fortnight of August recorded highest plant height and more dry matter production $(136.5 \mathrm{~cm}$ and 101.4 g plant-1 respectively) followed by D2- second fortnight of July $(133.5 \mathrm{~cm}$ and $97.99 \mathrm{~g}$ plant-1 respectively) and D1 - First fortnight of July $(130.6 \mathrm{~cm}$ and $94.75 \mathrm{~g}$ plant-1 respectively). With respect to fertilizer levels,F3- 37.5:75:37.5 NPK $\mathrm{kg} \mathrm{ha}^{-1}$ recorded higher plant height and dry matter production $(136.4 \mathrm{~cm}$ and $100.8 \mathrm{~g}$ plant-1 respectively) followed by $\mathrm{F}_{2}-31.25: 62.5: 31.25 \mathrm{NPK} \mathrm{kg} \mathrm{ha}^{-1}(134.9$ $\mathrm{cm}$ and 99.2 g plant-1 respectively) and $\mathrm{F}_{1}-25: 50: 25 \mathrm{NPK} \mathrm{kg} \mathrm{ha}^{-1}(129.3 \mathrm{~cm} 94.14$ g plant-1 respectively). And Local genotype recorded higher plant height and dry matter production $\left(134.0 \mathrm{~cm}\right.$ and $\left.98.55 \mathrm{~g} \mathrm{plant}^{-1}\right)$ compared to SUN-053 $(133.1 \mathrm{~cm}$ and 97.53 g plant $\left.^{-1}\right)$.

\section{Introduction}

Sunnhemp (Crotalaria juncea L., Fabaceae), a native of India, is fast growing annual crop. The genus name "Crotalaria" means 'rattle' and refers to the noise made by the seeds shaken in the mature pods. Species of this genus are wide spread throughout tropical, sub-tropical and to a lesser extent temperate country. The sunnhemp crop is native to India. The crop is known in India by various names like 'Sonai' or 'San' (Hindi), 'Sanpat' (Bengali), 'Tag' (Marathi), 'Vakku' (Malayalam) 'Sanpat' (Oriya), 'Janumu' (Telegu), 'Sanabu' (Kannada).

These states cover nearly 87 per cent of the total area under cultivation of sunnhemp crop. 
Among these states, Orissa alone produces 26 per cent of the total sunnhemp produced in the country. The most concentrated sunnhemp growing districts of U.P. are Varanasi and Jaunpur. Aurangabad and Jalana are the two main districts of Maharashtra which cultivate this crop in large scale. Ganjam District of Orissa grows this crop. Above five districts accounts for 20 percent of the country's area and 23 per cent of production. The fibre yield in the Balasore and Sundargarh districts of Orissa and Chittaur districts of Rajasthan is the highest in the country followed by Ganjam and Kalahandi districts of Orissa. (Hazraet al., 2011)

Sunnhemp is the fastest growing species of the genus and is very effective in smothering out weeds. Almost any well drained soil is suitable for kharif' crop. It grown during rainy season is mainly utilized as a green manure crop (Dempsey, 1975). For fibre, it is grown on fairly light well drained soil (alluvium soilold or new) having sandy loam or loamy textured soil that retains sufficient moisture.

Soil moisture per cent of 30 helps in good and effective germination. And it is an important source of natural fibre crops in India. Sunnhemp belongs to genus Crotolaria, which consists over 600 species of which Crotolariajuncea L., is the most popular green manure crop (Whyte and Trumple, 1953).

Apart from its green manuring value is gaining importance because of increasing demand for a specific grade fiber needed for manufacture of tissue paper and paper for currency as it contains high percentage of cellulose and low amount of lignin. However, the non-availability of good quality seed is one of the constraints in popularizing sunnhemp cultivation. Unfortunately, not much research work is carried out towards development of suitable agronomic techniques for seed production of sunnhemp to make available the quality seeds to the growers. Therefore, Standardization of seed production technology like optimum time of sowing, different genotypes and fertilizer level for seed production in Sunnhemp is not available.

High quality seed is the key to successful agriculture. Seed is the critical input in any agriculture system and high yield of quality seed can be obtained only with improved agro techniques. The non-availability of good quality seed is one of the constraints in popularizing the practice of green manuring with Sunnhemp. Hence, the present research is under taken to evaluate sunnhemp varieties on varied practice like optimum time of sowing, fertilizer level for seed production in sunnhemp. With these objectives the study was undertaken on "Effect of date of sowing and fertilizer application on seed yield and quality of Sunnhemp (Crotalaria junceaL.)"

\section{Materials and Methods}

The field experiment on Sunnhemp was carried out at Agricultural Research Station, Kalloli and seed quality studies were conducted at Seed Quality and Research Laboratory, National Seed Project (Crops), University of Agricultural Sciences, Dharwad. Kalloli, is situated in Northern Dry Zone of Karnataka and located at 740 48'96' North latitude, 160 13'70' East longitudes with an altitude of $553 \mathrm{M}$ above mean sea level. The field experiment was laid out in a double split plot design with three factors, Main plot: Dates of sowing (D), i.e. $D_{1^{-}} 1^{\text {st }}$ fortnight of July, $D_{2}-2^{\text {nd }}$ fortnight of July, $D_{3^{-}} 1^{\text {st }}$ fortnight of August. Sub-plot: Genotypes (G), i.e. $G_{1}-$ Local and $G_{2}-S U N-053$ and Sub subplots: Fertilizer levels (F), i.e. $F_{1}-25: 50: 25$ NPK $\mathrm{kg} \mathrm{ha}{ }^{-1}, \quad \mathrm{~F}_{2^{-}}$31.25:62.5:31.25 NPK $\mathrm{kg} \mathrm{ha}^{-1}$ and F3- 37.5:75:37.5 NPK kg ha ${ }^{-1}$.

The observation on plant height $(\mathrm{cm})$ and dry matter production $\left(\mathrm{g}\right.$ plant $\left.{ }^{-1}\right)$ were recorded at 
harvest stage.

\section{Results and Discussion}

The experimental results indicated that, higher the plant height and more dry matter production in $\mathrm{D}_{3} \mathrm{G}_{1} \mathrm{~F}_{3}(140.2 \mathrm{~cm}$ and $105.4 \mathrm{~g}$ plant $^{-1}$ respectively) treatment combination and depicted in Table 1.

In the present investigation, Plant height and dry matter production were more in the late date of sown crop. Among the date of sowing, $\mathrm{D}_{3^{-}} 1^{\text {st }}$ fortnight of August sown have recorded highest plant height and more dry matter production $(136.5 \mathrm{~cm}$ and $101.4 \mathrm{~g}$ plant $^{-1}$ respectively) compared to the crop sown on $\mathrm{D}_{1^{-}}$, July first fortnight $(103.6 \mathrm{~cm}$ and $\left.94.75 \mathrm{~g} \mathrm{plant}^{-1}\right)$. The value of growth parameter like plant height were significantly higher in $\mathrm{D}_{3}$-first fortnight of August compare to the July first fortnight this might be responsible for higher value of dry matter production in $\mathrm{D}_{3^{-}} 1^{\text {st }}$ fortnight of August. These results are in conformity with the findings of Das et al., (2014), who had also observed that jute crop sown on $9^{\text {th }}$ August significantly recorded higher seed yield and dry matter production compared to crop that sown on $25^{\text {th }}$ July and $24^{\text {th }}$ August. These results are also in conformity with the findings of Rima and Nabam (2013) for LAI and total dry matter production in cowpea and Yadav (2003) for plant height and number of pods in cowpea. Among genotypes, Local genotype recorded higher plant height and dry matter production $\left(134.0 \mathrm{~cm}\right.$ and $\left.98.55 \mathrm{~g} \mathrm{plant}^{-1}\right)$ compared to SUN-053 $(133.1 \mathrm{~cm}$ and $97.53 \mathrm{~g}$ plant $^{-1}$ ). This may be due to genetic potentiality of a genotype as it provides optimum growing condition such as temperature, light, humidity and rainfall. Similar findings were reported by Satish et al., (2006) in dhaincha genotype DH-1 significantly higher seed yield than genotype ND-3 (Fig. 1-3).

Fig.1 General view of date of sowing of sunnhemp Genotypes

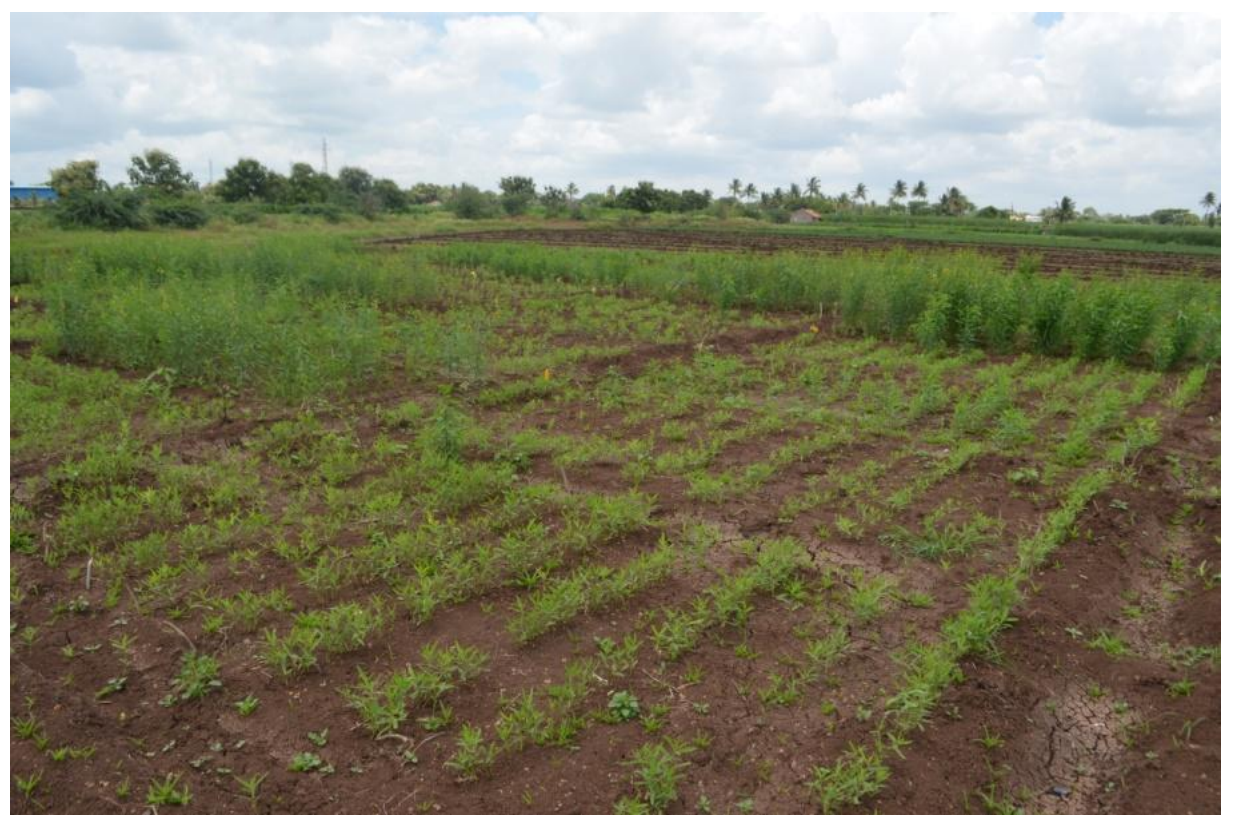


Table.1 Plant height and dry matter production at harvesting stage of sunnhemp as influenced by date of sowing, genotypes and fertilizer levels

\begin{tabular}{|c|c|c|c|c|c|c|c|c|c|c|c|}
\hline \multirow{2}{*}{\multicolumn{2}{|c|}{ Treatments }} & \multicolumn{5}{|c|}{ Plant height $(\mathrm{cm})$ at harvest } & \multicolumn{5}{|c|}{$\begin{array}{c}\text { Dry matter production }\left(\mathrm{g} \mathrm{plant}^{-1}\right) \text { at } \\
\text { harvest }\end{array}$} \\
\hline & & \multicolumn{3}{|c|}{ Fertilizer levels } & \multirow[b]{2}{*}{ Mean } & \multirow[b]{2}{*}{ Mean } & \multicolumn{3}{|c|}{ Fertilizer levels } & \multirow[b]{2}{*}{ Mean } & \multirow[b]{2}{*}{ Mean } \\
\hline $\begin{array}{l}\text { Date of } \\
\text { sowing }\end{array}$ & Genotype & $\mathbf{F}_{1}$ & $\mathbf{F}_{2}$ & $\mathbf{F}_{3}$ & & & $\mathbf{F}_{1}$ & $\mathbf{F}_{2}$ & $\mathbf{F}_{3}$ & & \\
\hline \multirow[t]{3}{*}{$\mathbf{D}_{1}$} & $\mathrm{G}_{1}$ & 126.9 & 131.8 & 134.4 & 131 & \multirow[t]{2}{*}{130.6} & 93.29 & 94.82 & 97.83 & 95.31 & \multirow[t]{2}{*}{94.75} \\
\hline & $\mathrm{G}_{2}$ & 125.2 & 131.5 & 134 & 130.2 & & 91.4 & 94.17 & 97.01 & 94.19 & \\
\hline & Mean & 129.5 & 135.4 & 137 & & & 94.24 & 99.94 & 101.5 & & \\
\hline \multirow[t]{3}{*}{$\mathbf{D}_{2}$} & $\mathrm{G}_{1}$ & 128 & 135.9 & 136.6 & 133.5 & \multirow[t]{2}{*}{133.5} & 93.39 & 100.4 & 101.2 & 98.32 & \multirow[t]{2}{*}{97.99} \\
\hline & $\mathrm{G}_{2}$ & 129.6 & 135 & 136.2 & 133.6 & & 94.72 & 98.55 & 99.69 & 97.65 & \\
\hline & Mean & 128.8 & 135.5 & 136.4 & & & 94.05 & 99.48 & 100.4 & & \\
\hline \multirow[t]{3}{*}{$\mathbf{D}_{3}$} & $\mathrm{G}_{1}$ & 133.6 & 138.6 & 140.2 & 137.5 & \multirow[t]{2}{*}{136.5} & 96.05 & 104.6 & 105.4 & 102 & \multirow[t]{2}{*}{101.4} \\
\hline & $\mathrm{G}_{2}$ & 132.6 & 136.7 & 137.2 & 135.5 & & 95.99 & 102.6 & 103.6 & 100.8 & \\
\hline & Mean & 133.1 & 137.6 & 138.7 & & & 96.02 & 103.6 & 104.5 & & \\
\hline \multicolumn{2}{|c|}{ Mean of $G_{1}$} & 129.5 & 135.4 & 137 & 134 & & 94.24 & 99.94 & 101.5 & 98.55 & \\
\hline \multicolumn{2}{|c|}{ Mean of $G_{2}$} & 129.1 & 134.4 & 135.8 & 133.1 & & 94.04 & 98.45 & 100.1 & 97.53 & \\
\hline \multicolumn{2}{|c|}{ Mean } & 129.3 & 134.9 & 136.4 & & & 94.14 & 99.2 & 100.8 & & \\
\hline \multicolumn{2}{|c|}{ Sources } & \multicolumn{3}{|c|}{ S. Em. \pm} & \multicolumn{2}{|c|}{ C. D. $(\mathrm{P}=0.05)$} & \multicolumn{3}{|c|}{ S.Em \pm} & \multicolumn{2}{|c|}{$\mathrm{CD}(\mathrm{P}=0.05)$} \\
\hline \multirow{2}{*}{\multicolumn{2}{|c|}{$\begin{array}{c}\text { Date of sowing (D) } \\
\text { Genotypes (G) }\end{array}$}} & \multicolumn{3}{|c|}{1.71} & \multicolumn{2}{|c|}{ NS } & \multicolumn{3}{|c|}{0.92} & \multicolumn{2}{|c|}{3.6} \\
\hline & & & 1.22 & & & & & 0.87 & & & \\
\hline ferti & lizer $(\mathbf{F})$ & & 2.02 & & & & & 0.97 & & & \\
\hline & $\square \mathbf{G}$ & & 2.12 & & & & & 1.5 & & & \\
\hline & $\square \mathbf{F}$ & & 3.5 & & & & & 1.68 & & & \\
\hline & $\square \mathbf{F}$ & & 2.86 & & & & & 1.37 & & & \\
\hline $\mathbf{D}$ & $\mathbf{G} \square \mathbf{F}$ & & 4.95 & & & & & 2.37 & & & \\
\hline & $\begin{array}{l}\mathrm{D}_{1}-1^{\text {st }} \text { fortnig } \\
\mathrm{G}_{1}-\text { Local } \\
\mathrm{F}_{1} \text { - 25:50:25 }\end{array}$ & $\begin{array}{l}\text { of July } \\
\mathrm{K} \mathrm{kg} / \mathrm{ha}\end{array}$ & $\begin{array}{l}\text { D } \\
\text { C } \\
\text { F }\end{array}$ & $\begin{array}{l}\text { nd } \\
\text { nd fortnig } \\
\text { UN-053 } \\
1.25: 62.5\end{array}$ & $\begin{array}{l}\text { of July } \\
1: 25 \mathrm{NPF}\end{array}$ & $\mathrm{g} / \mathrm{ha}$ & $D_{3^{-1}}$ & $75: 37.5 \mathrm{~N}$ & $\begin{array}{l}\text { ugust } \\
\mathrm{K} \mathrm{kg} / \mathrm{ha}\end{array}$ & & \\
\hline
\end{tabular}


Fig.2 Different dates of sowing of sunhemp genotypes

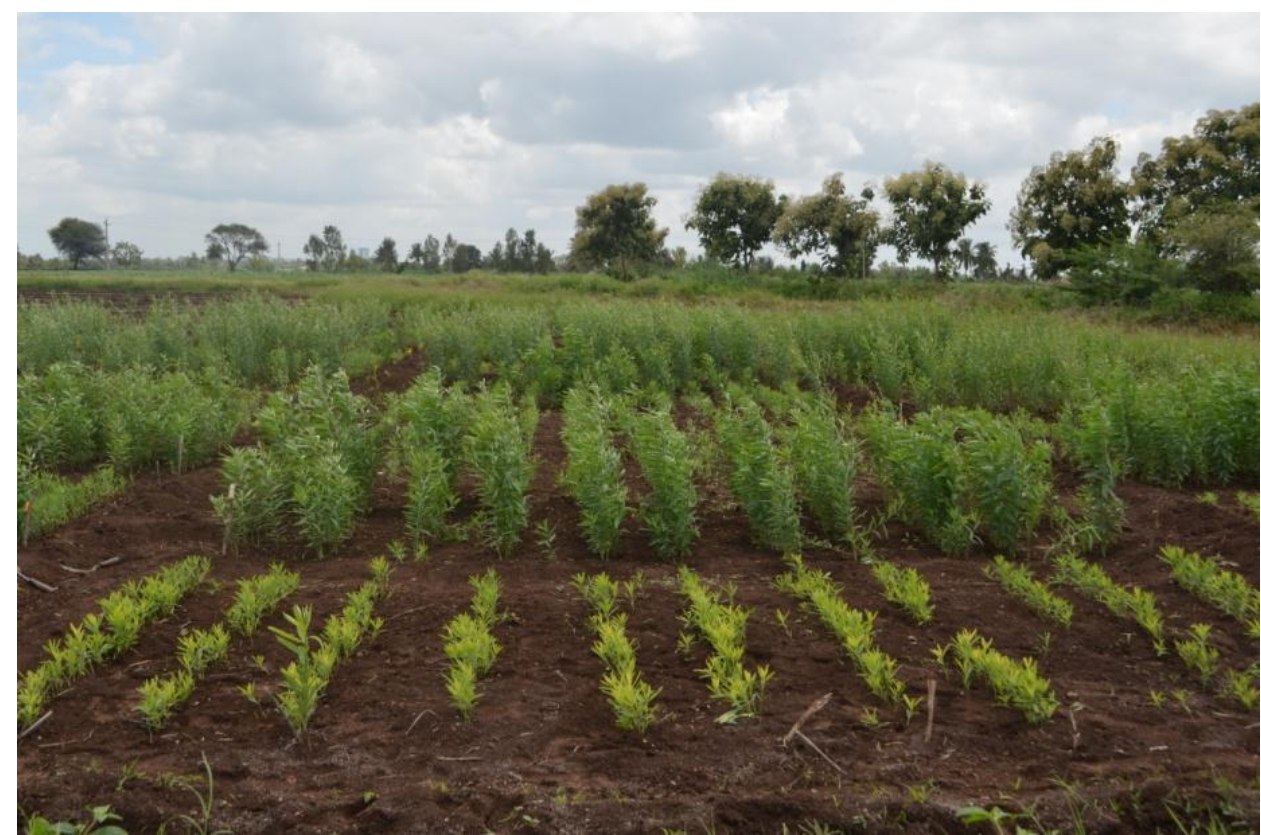

Fig.3 Dry matter production of sunnhemps as influenced by date of sowing, genotypes and fertilizer levels

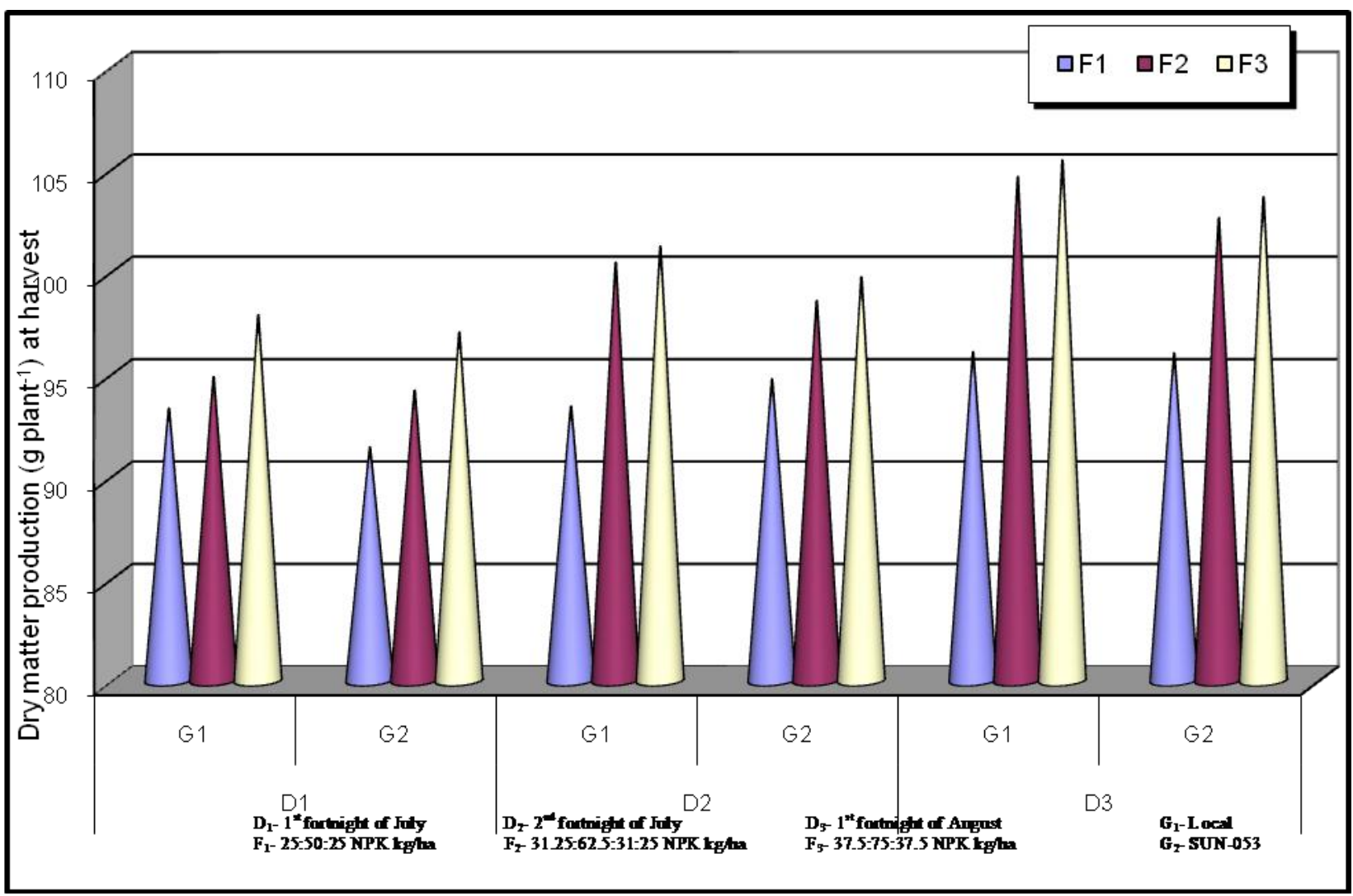


With respect to fertilizer, higher plant height and dry matter $\left(136.4 \mathrm{~cm}\right.$ and $\left.100.8 \mathrm{~g} \mathrm{plant}^{-1}\right)$ was recorded higher in fertilizer level, $\mathrm{F}_{3^{-}}$ 37.5:75:37.5 NPK $\mathrm{kg} \mathrm{ha}{ }^{-1}$ than medium fertilizer level of fertilizer level $\mathrm{F}_{2-}$ 31.25:62.5:31.25 NPK kg ha ${ }^{-1}(134.9 \mathrm{~cm}$ and 99.20 $\mathrm{g} \mathrm{plant}^{-1}$ ) and low $F_{1}-25: 50: 25$ NPK kg $\mathrm{ha}^{-1}\left(129.3 \mathrm{~cm}\right.$ and $\left.94.14 \mathrm{~g} \mathrm{plant}^{-1}\right)$ fertilizer level. Increase in the seed yield is due to increased availability of nutrient (nitrogen, phosphorus and potassium) causing accelerated photosynthetic rate and thus lead to the more production of photosynthesis. The maximum yield with high rate of fertilization could also be attributed to better performance of crop which was obviously for higher growth components like plant height and dry matter production that resulted in over medium $F_{2^{-}}$31.25:62.5:31.25 NPK kg ha ${ }^{-1}$ and low $\mathrm{F}_{1}-25: 50: 25$ NPK $\mathrm{kg} \mathrm{ha}^{-1}$ fertilizer levels. These results are in conformity with the finding of Santosh et al., (2010), Gupta (2006).

In conclusion, the interaction effect of Date of sowing and genotypes, date of sowing and fertilizer, genotypes and fertilizer, Date of sowing. Genotypes and fertilizer were found non-significant. Among the fertilizer, genotype and date of sowing $\mathrm{D}_{3} \mathrm{G}_{1} \mathrm{~F}_{3}$ were recorded highest plant height and dry matter production.Further, this treatment resulted in better yield components, higher seed yield and better seed quality traits.

\section{Acknowledgement}

I place on record my deep and my heartfelt gratitude and sincere thanks to Mr. Eshanna, M. R, Associate Professor, Department of Seed Science And Technology, Agricultural Research Station Kalloli, University of Agricultural Sciences, Dharwad and chairman of my Advisory Committee for his constant inspiration and encouragement, timely help, valuable advice and friendly attitude throughout the study period. It is rather difficult to express in words my sincere and heartfelt gratitude to the members of my Advisory Committee, Dr. V. K. Deshpande, Professor, DSS \&T, UASD and Dr. S. S. Hallikeri., Professor, Department of Agronomy, Agricultural Research Station Arabhavi, University of Agricultural Sciences, Dharwad. Dr. B. S. Vyakaranhal Professor and to Dr. D. S. Uppar Professor and Head, Department of Seed Science and Technology, UAS, Dharwad, for their co-operation extended to me during the course of my study and research.

\section{References}

Das, H., Poddar, P., Haque, S., Pati., S., Poddar, R. and Kundu, C.K., 2014, Seed yield and economics of white jute as influenced by different date of sowing, spacing and topping schedule in terai region of West Bengal. Intl J. Farm Sci., 4(4):51-58.

Dempsey, J. M., 1975, Fibre Crops. University Press of Florida. Gainesville.

Gupta, S., 2006, Effect of nutrients and plant density on growth and yield of garden cress (Lepidium sativum L.). M. Sc. (Hort.) Thesis, Univ. Agril. Sci., Bangalore, Karnataka, (India).

Hazra, S. K., Singh, D. P. and Chaudhury, J., 2011, Studies in agronomic management practice for sunhemp seed production. Annual report of central research institute for jute and allied fibres, Barakhpur, West Bengal, pp. 81-89.

Rima, T. and Nabam, A. T., 2013, Impact of Time of Sowing, Spacing and Seed Rate on Potential Seed Production and Fodder Quality of Cowpea (Vigna unguiculata). J. Agric. Veterinary Sci., pp.61-68. 
Satish, K., Singh, R. C. and Kadian, V. S., 2006, Response of dhaincha (Sesbania aculeata) genotypes sowing dates and row spacing. IndianJ.Agron., 51(2): 152-153.

Santosh, C., Keshwa, G. L. and Yadav, L. R., 2010, Effect of sowing dates, row spacing and nitrogen levels on productivity, quality and economics of garden cress (Lepidium sativum). Indian J. Agric. Sci., 80(8): 752-754.

Yadav, G. L., 2003, Effect of sowing time, row spacing and seed rate on yield of cowpea under rainfed condition. Indian J. Pulse Res., 16(2): 157-15.

Whyte, K. S. and Trumple, D. W., 1953, Sunnhemp utilized as a legume cover crop for corn production. Agron. J., 97(1): 48-49.

\section{How to cite this article:}

Sanggonda, M.R. Eshanna and Priyanka, M. 2019. Effect of Dates of Sowing and Fertilizer on Growth and Seed Yield of Sunnhemp Genotypes. Int.J.Curr.Microbiol.App.Sci. 8(11): 22162222. doi: https://doi.org/10.20546/ijcmas.2019.811.258 